\title{
Changes in biomass and chemical composition of spider crab (Hyas araneus) larvae reared in the laboratory
}

\author{
Klaus Anger, Norbert Laasch, Cornelia Püschel and Franziska Schorn \\ Biologische Anstalt Helgoland, Meeresstation, D-2192 Helgoland, Federal Republic of Germany
}

\begin{abstract}
Larval and early post-larval growth has been investigated in Hyas araneus L. (Majidae) reared in the laboratory. Growth was measured as dry weight (DW), ash-free dry weight (AFDW), carbon $(\mathrm{C})$, nitrogen $(\mathrm{N})$, hydrogen $(\mathrm{H})$, gross biochemical constituents (protein, lipid, carbohydrate, chitin, ash) and energy (calculated separately from carbon and biochemical composition). During larval development, i. e. from freshly hatched zoea-I to late megalopa, all these criteria of biomass increase by factors ranging between 5 and 14; carbohydrate shows the lowest, chitin the highest increment. There are indications of loss in organic body weight during the latest period preceding metamorphosis to the crab stage. When no food is offered during this time, megalopae lose significantly more biomass than control larvae. This suggests that food is still required, but feeding activity is reduced to a level below maintenance ingestion rate. Following metamorphosis, the juvenile crab accumulates biomass at a far higher absolute rate (expressed as $\mu \mathrm{g} \mathrm{d}^{-1}$ ) than all larval stages. This alteration in growth pattern is attributed to lack of further morphological changes. Among the biochemical constituents, protein is most prominent ( 50 to $68 \%$ AFDW), followed by lipid ( 17 to $30 \%$ ) and chitin ( 7 to $17 \%$ ). Carbohydrates play a minor role contributing only 1.6 to $3.7 \%$ of AFDW. The percentage of protein increases during zoeal development; later it decreases. This pattern is inversely related to changes in ash content, which ranges from 19 to $30 \%$ DW. Lipid (\% AFDW) shows a decreasing tendency during larval development. Separate calculations of energy content from $C$ and from biochemical composition yield systematic differences, the former usually being lower than the latter. Only in late megalopae is this pattern inverted, presumably due to inorganic $\mathrm{C}$ in the increasingly calcified cuticle of this stage. Non-linear regression equations are given for conversions of $\mathrm{C}$ to protein, lipid, and carbohydrate, $\mathrm{N}$ to protein, and $\mathrm{H}$ to lipid. The relationship between $\mathrm{N}$ and protein suggests that non-protein, non-chitin $\mathrm{N}$ may also be important, and calculation of protein by multiplication of total $\mathrm{N} \times 6.25$ results in an overestimation of protein.
\end{abstract}

\section{INTRODUCTION}

Growth patterns and changes in the elemental and biochemical composition of crab larvae developing under controlled conditions are little known. In their 1970 review, Yamaoka and Scheer stated: 'Though little is known about adult growth, even less is known about the chemistry of the growth and development of crustacean larvae.' Since suitable rearing techniques have become available, an increasing number of papers has been published in the last few years dealing with larval biochemistry and energetics (for recent reviews see Anger and Dawirs, 1982; Dawirs, in press).

Also comparative data on biomass of crustaceans isolated from plankton samples have increased (e.g.
Raymont et al., 1967 and earlier papers cited therein; Omori, 1969; Childress and Nygaard, 1974; Ikeda, 1974; Mayzaud and Martin, 1975; Youngbluth, 1982). These studies have the disadvantage that the origin, the previous history, and sometimes even the identity of the material analysed is unknown. Such information is necessary, however, because it is uncertain as to what extent laboratory data may be extrapolated to field conditions.

Larvae of the common spider crab Hyas araneus, occurring on both sides of the northern Atlantic Ocean, have recently become one of the standard subjects of experimental studies on various aspects of crustacean larval ecology and energetics (Christiansen, 1971; Christiansen and Størmer, 1978; Anger and Nair, 1979; 
Anger and Dawirs, 1981, 1982; Kunisch, 1982). The present paper presents data on larval and early postlarval biomass (dry weight, ash-free dry weight), elemental (carbon, nitrogen, hydrogen), and gross biochemical composition (protein, lipid, carbohydrate chitin) as well as on caloric content in relation to the stage of development. Quantitative interrelationships between some of these measures of biomass are analysed to allow approximate conversions in future studies.

\section{MATERIALS AND METHODS}

\section{Obtaining and handling of larvae}

Ovigerous females of Hyas araneus were dredged during the winter $1981 / 82$ from ca. 30 to $50 \mathrm{~m}$ depth near Helgoland (German Bight, North Sea) and maintained in the laboratory at $2^{\circ} \mathrm{C}$. Larvae were collected later in a flow-through system at $6{ }^{\circ} \mathrm{C}$ (for further details see Anger and Dawirs, 1981), and then massreared at constant $12^{\circ} \mathrm{C}$; by means of a wide-bore pipette, they were placed in culture bowls (diameter: $14 \mathrm{~cm}$ ) with ca. $800 \mathrm{ml}$ of filtered sea water (stratified filter; pore size ca. $1 \mu \mathrm{m}$ ). Initial population density was 50 zoeae bowl ${ }^{-1}$. Dead larvae and faecal matter were removed daily. Sea water (filtered; ca. 32\% S) and food (freshly hatched Artemia sp., San Francisco Bay Brand, and Brachionus plicatilis) were changed every second day.

When moults occurred, exuviae were removed, and freshly moulted individuals were transferred at daily intervals to new labelled bowls. In this way it was assured that the age at each particular developmental stage was known for all larvae.

Analyses were carried out: (1) within a few hours after hatching or moulting (later referred to as $0 \mathrm{~d}$ for a given stage); (2) shortly (ca. 1 d) before moulting to the following developmental stage (i. e. after $10 \mathrm{~d}$ for zoea-I, $12 \mathrm{~d}$ for zoea-II, and $21 \mathrm{~d}$ for megalopa and crab); (3) in megalopa and crab stages also at intermediate steps of development.

\section{Dry weight and elemental analyses}

Larvae were removed from defined cultures by means of wide-bore pipettes and transferred to filtered sea water. They were then briefly rinsed in water from an ion exchanger, blotted on filter paper (fluff-free), and freeze-dried over night in preweighed tin cartridges as described in more detail by Anger and Dawirs (1982). After determination of larval dry weights on an Autobalance AD-2 (Perkin-Elmer), car- bon $(\mathrm{C})$, nitrogen $(\mathrm{N})$, and hydrogen $(\mathrm{H})$ were measured in a C-H-N analyzer (Model 1106, Carlo Erba Science). For each measurement of dry weight and elemental composition, 5 to 10 zoea-I, 3 to 5 zoea-II, 2 to 3 megalopae, or 1 juvenile crab, respectively, were used. Each determination consisted of 12 to 42 replicates. In this way, a total of 259 analyses were carried out comprising 136 zoea-I, 96 zoea-II, 271 megalopae, and 80 crabs, i. e. a total of 583 individuals. Due to technical failures of the analyzer, some data (in particular on nitrogen) were lost (Table 1).

In 10 - $d$ old zoea-I larvae no nitrogen values were obtained. In this case $8.3 \%$ of dry weight was assumed (taken from Anger and Dawirs, 1982) to complete figures for further comparisons.

\section{Biochemical analyses}

Material from identical cultures was rinsed, blotted, and freeze-dried as described above. Ash content was ascertained in the following way: in 5 to 15 zoeae, 2 to 6 megalopae, or 1 crab, respectively, dry weight was measured in preweighed silver cartridges. Then they were ashed in a muffle furnace at $500^{\circ} \mathrm{C}$ for $4 \mathrm{~h}$, as recommended by Hirota and Szyper (1975), cooled in a desiccator to room temperature, and weighed again. A total of 94 such determinations was carried out with 255 zoea-I, 78 zoea-II, 121 megalopae, and 31 crabs (total: 485 individuals)

Ash-free dry weight and all further data related to it were calculated from percentage values of ash as obtained above, but applying absolute dry weights determined before elemental analyses. In this way all data on elemental and biochemical composition can be directly compared.

Determination of content of protein, total lipid and total carbohydrate was carried out as follows: at least 3 to $5 \mathrm{mg}$ of freeze-dried animals were thoroughly homogenized in an agate mortar and suspended in $500 \mu \mathrm{l}$ of water by exposure to ultrasonics. This homogenate was fractionated as described by Holland and Hannant (1973) with the following modifications: all centrifugation steps were carried out at $800 \mathrm{~g}$ for 2 min; precipitate after lipid extraction was discarded; fractionation of lipids was not carried out; precipitated proteins were resolved at $52^{\circ} \mathrm{C}$.

Proteins were determined in accordance with Lowry et al. (1951) applying the following procedure: $200 \mu \mathrm{l}$ of protein sample were mixed with $2 \mathrm{ml}$ of reagent $\mathrm{A}$ [ $2 \% \mathrm{Na}_{2} \mathrm{CO}_{3}$ in $0.1 \mathrm{~N} \mathrm{NaOH}$ and $0.5 \% \mathrm{CuSO}_{4} \times 5 \mathrm{H}_{2} \mathrm{O}$ in $1 \% \mathrm{Na}$-citrate, $50: 1$ ]. After $10 \mathrm{~min} 2 \mathrm{ml}$ of reagent $\mathrm{B}$ [Folin-Ciocalteu's reagent (E. Merck, Darmstadt, FRG) in $1: 1$ dilution with distilled water] were added, the 
sample was thoroughly mixed and incubated for $1 \mathrm{~h}$ at $20^{\circ} \mathrm{C}$. Then $\mathrm{E}_{750}$ was measured versus a blank in a double beam spectrophotometer. Bovine serum albumin was used as a standard.

Total lipids were determined by the method of Marsh and Weinstein (1966), applying the procedure described by Holland and Gabbot (1971). Tripalmitin was used as a standard. The determination of total carbohydrates was carried out according to the method of Folin and Malmros (1929), modified by Holland and Gabbot (1971) using glucose as a standard.

Determination of chitin was carried out with 3 to $5 \mathrm{mg}$ of freeze-dried and thoroughly disrupted animals following the method of Raymont et al. (1964).

Energy content was calculated in 2 ways: (1) from carbon ( $\mathrm{N}$-corrected conversion given by Salonen et al., 1976); (2) from biochemical constituents (factors given by Winberg, 1971): $23.64 \mathrm{~J} \mathrm{mg}^{-1}$ protein, 17.15 $\mathrm{Jmg}^{-1}$ cabohydrate, and $39.54 \mathrm{~J} \mathrm{mg}^{-1}$ lipid. Chitin was considered as a carbohydrate.

\section{RESULTS}

\section{Accumulation of biomass during larval and early postlarval growth}

All 3 larval stages (the non-feeding pre-zoea is not considered here) accumulate a high amount of biomass: from hatching to metamorphosis (i.e. late megalopa stage) dry weight (DW) is increased by a factor of 8.9 (i.e. a gain of $790 \%$ ), ash-free dry weight (AFDW) and carbon (C) by 8.7 each, nitrogen by 7.7 , hydrogen and ash contents by 10.5 each (Tables 1 and 2, Fig. 1). The biochemical constituents protein, lipid, carbohydrate, and chitin are increased during the same time by factors of $6.8,5.3,4.8$, and 14.4 , respectively.

Since biomass growth patterns within larval stages are non-linear (Anger and Dawirs, 1982; cf. megalopa in Fig. 1), average figures of daily biomass accumulation rates obtained by linear interpolations can only be

Table 1 Hyas araneus. Dry weight (DW), ash-free dry weight (AFDW), carbon (C), nitrogen (N), hydrogen ( $H)$, C/N and C/H ratios during larval and early post-larval development. Age: days within each stage. Arithmetic mean $(\bar{x})$, standard deviation ( \pm ), and number of measurements $(\mathrm{n}) . \cdot \cdots$ : megalopa larvae starved from Days 14 to 21 , maintained communally or individually

\begin{tabular}{|c|c|c|c|c|c|c|c|c|c|c|c|c|c|c|c|c|c|c|c|c|c|c|}
\hline \multirow[t]{2}{*}{ Stage } & \multirow{2}{*}{$\begin{array}{l}\text { Age } \\
\text { (d) }\end{array}$} & \multicolumn{3}{|c|}{ DW $(\mu \mathrm{g})$} & \multicolumn{3}{|c|}{ AFDW $(\mu g)$} & \multicolumn{3}{|c|}{$C(\mu g)$} & \multicolumn{3}{|c|}{$N(\mu g)$} & \multicolumn{3}{|c|}{$\mathrm{H}(\mu \mathrm{g})$} & \multicolumn{3}{|c|}{$C / N$} & \multicolumn{3}{|c|}{$\mathrm{C} / \mathrm{H}$} \\
\hline & & $\bar{x}$ & \pm & $n$ & $\bar{x}$ & \pm & $\mathrm{n}$ & $\bar{x}$ & \pm & $\mathrm{n}$ & $\overline{\mathrm{x}}$ & \pm & $\mathrm{n}$ & $\overline{\mathrm{x}}$ & \pm & $\mathrm{n}$ & $\overline{\mathrm{x}}$ & \pm & $n$ & $\overline{\mathrm{x}}$ & \pm & $n$ \\
\hline Zoea I & 0 & 63 & 2 & 14 & 46 & 1 & 17 & 25.4 & 0.3 & 13 & 6.2 & 0.1 & 13 & 3.1 & 0.8 & 13 & 4.1 & 0.1 & 13 & 8.2 & 0.1 & 13 \\
\hline Zoea I & 10 & 159 & 5 & 12 & 124 & 2 & 7 & 69.0 & 1.8 & 12 & & & 0 & 9.4 & 0.2 & 11 & & & 0 & 7.4 & 0.1 & 12 \\
\hline Zoea II & 0 & 159 & 7 & 12 & 126 & 3 & 8 & 63.3 & 2.3 & 12 & 14.3 & 0.3 & 10 & 9.2 & 0.5 & 12 & 4.4 & 0.1 & 10 & 6.9 & 0.7 & 12 \\
\hline Zoea II & 12 & 304 & 11 & 12 & 247 & 4 & 6 & 133.2 & 5.3 & 12 & 28.7 & 0.8 & 12 & 19.2 & 1.0 & 10 & 4.6 & 0.2 & 12 & 6.9 & 0.1 & 10 \\
\hline Megalopa & 0 & 330 & 23 & 25 & 257 & 4 & 6 & 133.3 & 8.4 & 25 & 30.4 & 1.8 & 23 & 18.9 & 1.4 & 24 & 4.4 & 0.3 & 23 & 7.1 & 0.3 & 24 \\
\hline Megalopa & 7 & 518 & 32 & 26 & 364 & 6 & 9 & 205.6 & 15.2 & 24 & 44.2 & 2.7 & 25 & 29.0 & 2.0 & 13 & 4.6 & 0.2 & 24 & 6.9 & 0.2 & 13 \\
\hline Megalopa & 14 & 585 & 112 & 26 & 414 & 33 & 10 & 229.3 & 59.2 & 26 & 49.4 & 6.6 & 24 & 33.7 & 10.6 & 25 & 4.6 & 0.6 & 24 & 6.9 & 0.5 & 25 \\
\hline Megalopa & 21 & 555 & 60 & 27 & 400 & 46 & 8 & 220.2 & 24.3 & 27 & 47.7 & 7.1 & 27 & 32.2 & 4.4 & 27 & 4.6 & 0.4 & 27 & 6.8 & 0.3 & 27 \\
\hline Megalopa & 21 & 497 & 27 & 13 & & & 0 & 178.3 & 14.7 & 13 & 37.5 & 1.5 & 13 & 24.7 & 2.5 & 13 & 4.7 & 0.2 & 13 & 7.2 & 0.2 & 13 \\
\hline Megalopa & $21^{\cdots}$ & 486 & 19 & 12 & 322 & 16 & 15 & 173.5 & 7.8 & 12 & 36.6 & 1.3 & 12 & 24.1 & 1.2 & 12 & 4.7 & 0.1 & 12 & 7.2 & 0.1 & 12 \\
\hline Crab & 0 & 420 & 59 & 22 & 323 & 59 & 22 & 166.8 & 16.1 & 21 & 40.9 & 3.1 & 21 & 22.2 & 3.2 & 21 & 4.0 & 0.3 & 20 & 7.6 & 0.5 & 21 \\
\hline Crab & 14 & 1148 & 135 & 42 & 555 & 138 & 42 & 345.1 & 46.3 & 42 & 68.7 & 7.1 & 42 & 44.1 & 7.2 & 36 & 5.0 & 0.2 & 42 & 7.7 & 0.4 & 36 \\
\hline Crab & 21 & 1376 & 166 & 16 & 692 & 166 & 16 & 434.3 & 55.1 & 16 & 93.8 & 8.8 & 16 & 55.0 & 8.3 & 16 & 4.6 & 0.2 & 16 & 7.9 & 0.2 & 16 \\
\hline
\end{tabular}

Table 2. Hyas araneus. Gross biochemical constituents in larvae and freshly metamorphosed crabs. For further explanation see Table 1

\begin{tabular}{|c|c|c|c|c|c|c|c|c|c|c|c|c|c|c|c|c|}
\hline \multirow[t]{2}{*}{ Stage } & \multirow{2}{*}{$\begin{array}{l}\text { Age } \\
\text { (d) }\end{array}$} & \multicolumn{3}{|c|}{ Protein ( $\mu \mathrm{g})$} & \multicolumn{3}{|c|}{ Lipid $(\mu g)$} & \multicolumn{3}{|c|}{ Carbohydrate $(\mu g)$} & \multicolumn{3}{|c|}{ Chitin $(\mu g)$} & \multicolumn{3}{|c|}{ Ash $(\mu g)$} \\
\hline & & $\bar{x}$ & range & $\mathrm{n}$ & $\bar{x}$ & range & $n$ & $\bar{x}$ & range & $\mathrm{n}$ & $\bar{x}$ & range & $\mathrm{n}$ & $\bar{x}$ & \pm & $\mathrm{n}$ \\
\hline Zoea I & 0 & 27.5 & $26.0-29.1$ & 2 & 13.8 & $13.6-14.0$ & 2 & 1.3 & $0.7-1.9$ & 2 & 4.3 & & 2 & 16.5 & 1.0 & 17 \\
\hline Zoea I & 10 & 72.6 & $69.3-76.0$ & 2 & 29.3 & $29.2-29.4$ & 2 & 4.6 & $4.5-4.7$ & 2 & 20.5 & & 1 & 35.2 & 1.7 & 7 \\
\hline Zoea II & 0 & 81.8 & $81.4-82.3$ & 2 & 36.8 & $35.2-38.8$ & 2 & 3.4 & $2.9-3.8$ & 2 & 14.4 & & 1 & 33.4 & 2.7 & 8 \\
\hline Zoea II & 12 & 167.0 & $163.7-170.4$ & 2 & 50.7 & $42.8-60.1$ & 3 & 6.2 & $6.1-6.4$ & 2 & 26.1 & & 1 & 56.8 & 3.7 & 6 \\
\hline Megalopa & 0 & 140.3 & $139.0-141.3$ & 2 & 54.9 & $52.0-57.8$ & 2 & 6.4 & $6.3-6.6$ & 2 & 18.2 & & 1 & 71.8 & 2.7 & 6 \\
\hline Megalopa & 7 & 205.4 & $175.1-235.8$ & 4 & 64.2 & $58.0-74.6$ & 5 & 7.7 & $5.9-9.6$ & 3 & 49.6 & $47.6-51.6$ & 2 & 153.9 & 5.7 & 9 \\
\hline Megalopa & 14 & 223.5 & $160.6-296.2$ & 4 & 74.6 & $61.7-87.6$ & 4 & 8.5 & $7.0-10.9$ & 3 & 59.8 & $49.9-69.8$ & 2 & 172.1 & 11.0 & 10 \\
\hline Megalopa & 21 & 212.2 & $175.6-244.5$ & 4 & 72.8 & $49.6-97.7$ & 4 & 6.3 & $5.7-7.1$ & 3 & 62.1 & $53.7-70.5$ & 2 & 155.6 & 16.7 & 8 \\
\hline Megalopa & $21^{\cdots}$ & 156.7 & $154.1-159.4$ & 2 & 42.3 & $39.8-44.7$ & 2 & 3.2 & $3.2-3.3$ & 2 & 50.1 & & 1 & 164.2 & 15.7 & 15 \\
\hline Crab & 0 & 160.6 & $151.6-169.4$ & 2 & 61.3 & & 1 & 7.8 & $7.6-8.0$ & 2 & 39.9 & & 1 & 96.9 & 17.6 & 8 \\
\hline
\end{tabular}




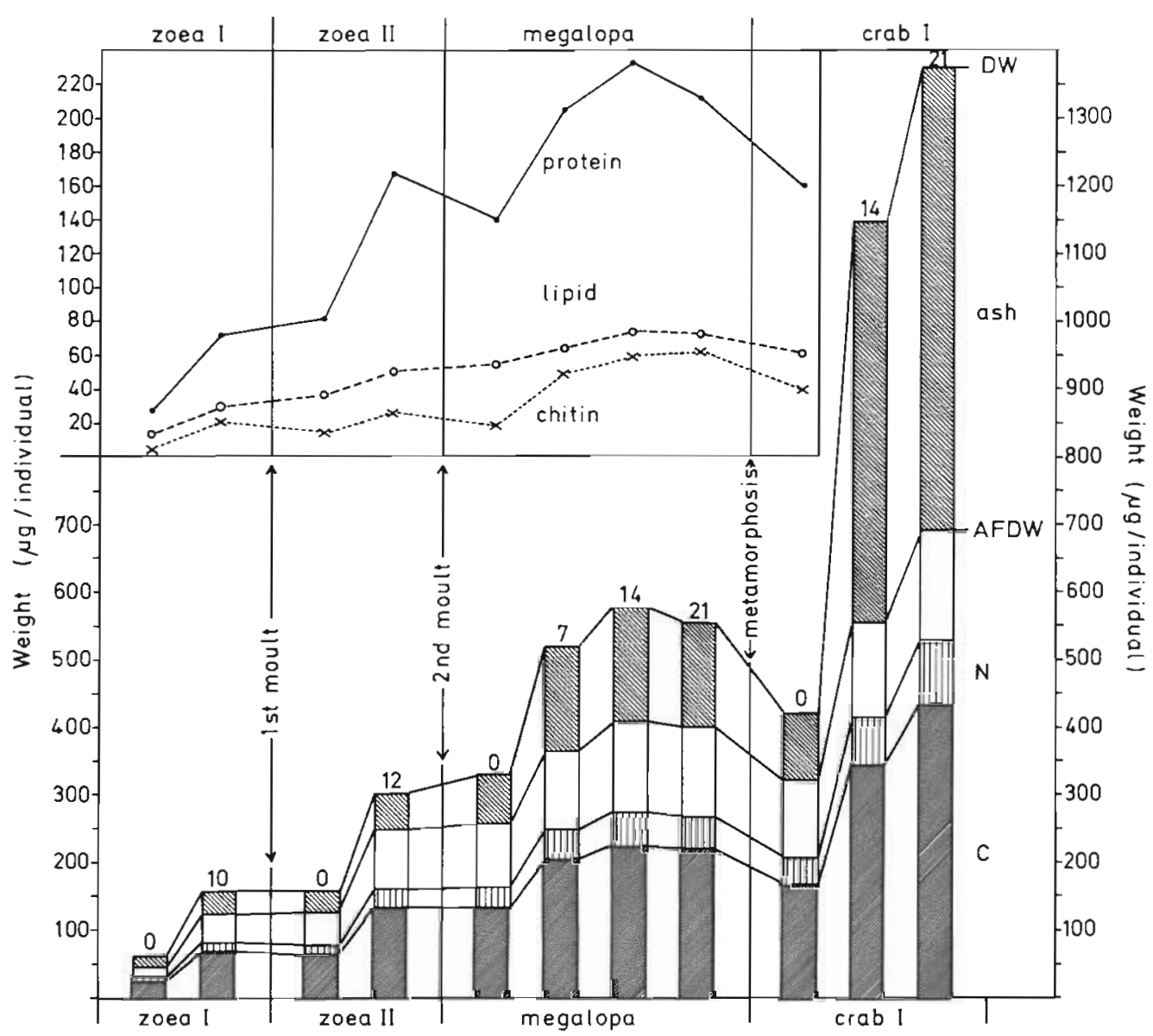

Fig. 1. Hyas araneus. Larval and early post-larval growth, expressed as dry weight (DW), ash-free dry weight (AFDW), carbon (C), nitrogen ( $\mathrm{N}$ ), and some gross biochemical constituents. Numbers on top of columns: age (days) for each stage

used as first approximations and for comparisons between different stages: the absolute rate of accumulation $\left(\mu \mathrm{g} \mathrm{d}^{-1}\right)$ was found to increase from the first to the second zoeal stage, then it decreased in the megalopa, and increased substantially again after metamorphosis (DW, AFDW, C, and $\mathrm{N}$ taken as examples in Fig. 2). When these accumulation rates are related to the initial weight in each stage, percent accumulation per day shows a conspicuous decrease throughout larval life, but again an increase in juvenile crabs (Fig. 2).

Growth patterns in the zoeal stages of Hyas araneus have been documented in detail by Anger and Dawirs (1982); their data of elemental composition compare favourably with those of the present study. In megalopae, likewise a decreasing biomass during the last period preceding metamorphosis was found. This was most pronounced in protein (Fig. 1). Anger and Dawirs (1982) suggested that the megalopa possibly does not take up food during this period. The following experiment was conducted to test this hypothesis:

Parallel to the megalopae treated as described above, 120 individuals in the same stage were fed normally for $14 \mathrm{~d}$. Thereafter, they were starved for $7 \mathrm{~d}$, 90 of them kept individually in vials (methods: Anger and Dawirs, 1981), 30 maintained communally in a bowl, such as fed larvae, to check for possible cannibalism.

Surprisingly, in the latter group no cannibalism occurred. A single individual died, but was not eaten. DW, C, N and $\mathrm{H}$ were almost identical in both groups (Table 1). Biochemical composition and ash content were determined only in the group starved individually; however, according to all other measures of biomass there was probably no difference either between the two groups. These findings support the above hypothesis.

When biomass values of these temporarily starved megalopae are compared, however, with those found in 21-d old individuals fed continuously, there are highly significant differences (in all cases $\mathrm{p}<0.001$ ) in DW, AFDW, C, N, and $\mathrm{H}$. Also in biochemical constituents marked decreases were found in starved larvae (Table 2): $55 \mu \mathrm{g}(26 \%$ ) in protein, $30 \mu \mathrm{g}(42 \%)$ in lipid, $3 \mu \mathrm{g}(49 \%)$ in carbohydrates, and $12 \mu \mathrm{g}(19 \%)$ in 


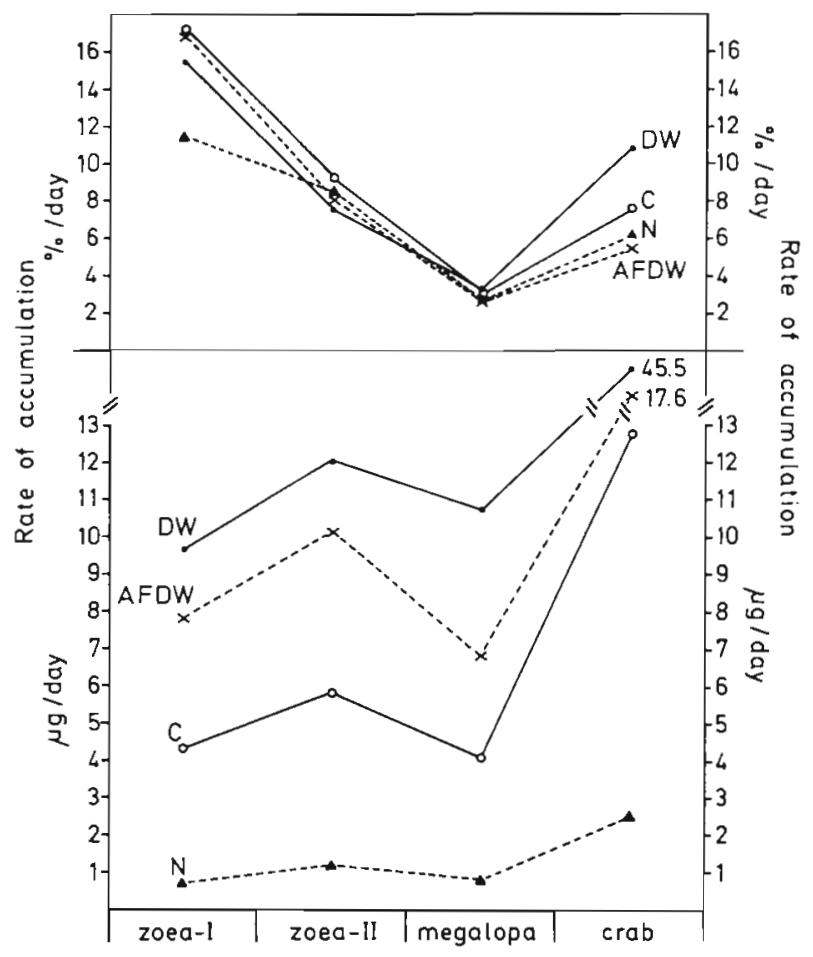

Fig. 2. Hyas araneus. Average rate of biomass accumulation during 3 larval stages and the first juvenile stage. Percentages (upper graph) related to initial weight in each stage. Abbreviations as in Fig. 1

chitin. In contrast to these losses, ash content increased by $9 \mu \mathrm{g}(6 \%)$. Although the exact amount of these differences must remain uncertain because of generally very high variation in biomass of the megalopa stage, their consistency, in accordance with the above findings in elemental composition, strongly suggests that the megalopa stage normally does take up food even after Day 14. Thus, the significance of decreasing biomass in fed megalopae approaching metamorphosis remains unclear.

\section{Accumulation of energy}

Since caloric values were estimated from both elemental and biochemical composition, patterns of absolute energy accumulation were similar to biomass growth (Fig. 3; cf. Fig. 1). Caloric equivalents calculated from (1) carbon and (2) all biochemical compounds measured, however, show striking differences: the former values are always conspicuously higher than the latter, when zoeae or freshly moulted later stages are considered. In older megalopae the opposite is found (Fig. 3). From these findings 2 conclusions are suggested: (1) the regression equation by Salonen et al. (1976) underestimates actual caloric contents in zoeae and in freshly moulted later stages of Hyas araneus; (2) in megalopae having a hardened exoskeleton, there must be considerable amounts of inorganic carbon leading to an overestimation of energetic values.

Since chitin is a substance practically indigestible by predatory zooplankton and fish, energy equivalents disregarding it were also calculated from biochemical composition (Fig. 3). The values range from ca. 22 to 25 $\mathrm{J}_{\mathrm{mg}}{ }^{-1}$ AFDW (17 to $18 \mathrm{~J} \mathrm{mg}^{-1} \mathrm{DW}$ ) in zoeal stages, and from ca. 17 to $20 \mathrm{~J} \mathrm{mg}^{-1}$ AFDW (12 to $16 \mathrm{Jmg}^{-1} \mathrm{DW}$ ) in megalopae and juvenile crabs.

Megalopae starved from Day 14 to Day 21 had significantly lower energetic values than individuals fed continuously. Depending on the way of estimating caloric contents, ca. 20 to $30 \%$ of energy per individual was lost during the period of food deprivation.

\section{Changes in chemical composition during larval and early postlarval growth}

Elemental composition of larval and early juvenile Hyas araneus was fairly constant (Fig. 4). Regular changes can be seen in carbon and hydrogen: their relative amounts ( $\%$ AFDW) decreased during each moult, thereafter increasing again. During development there is a slight increasing tendency. Changes in nitrogen appear regular. The $\mathrm{C}: \mathrm{N}$ ratio was found to increase within each stage, and during each moult it decreased again (Table 1 ). In the $\mathrm{C}: \mathrm{H}$ ratio no clear trends could be observed in the course of development.

Ash content showed a continuously decreasing trend throughout zoeal development with a minimum of $18.7 \%$ in the late zoea-II stage (Fig. 5). In the megalopa there is obviously already considerable calcification of the cuticle: the proportion of ash was ca. 28 to $30 \%$ DW. In freshly metamorphosed crabs it was only 16 to $27 \%$ (mean value: 23.1). This wide range apparently was caused by very rapid calcification of the juvenile cuticle taking place within less than $1 \mathrm{~d}$. Older crabs had ash contents of ca. $50 \%$ DW (Table 1).

Protein was the main biochemical component in all larvae and juveniles analysed. Its share of biomass increased during zoeal development from ca. 59 to $68 \%$ AFDW, then decreased to 53 to $56 \%$ in the megalopa, and to $50 \%$ in the freshly metamorphosed crab (Fig. 5).

Lipid content ranged from ca. 33 to $50 \%$ the protein level. It showed a clear cyclical pattern with decreases during each stage and increases after each moult (Fig. 5). In the course of development there was a conspicu- 


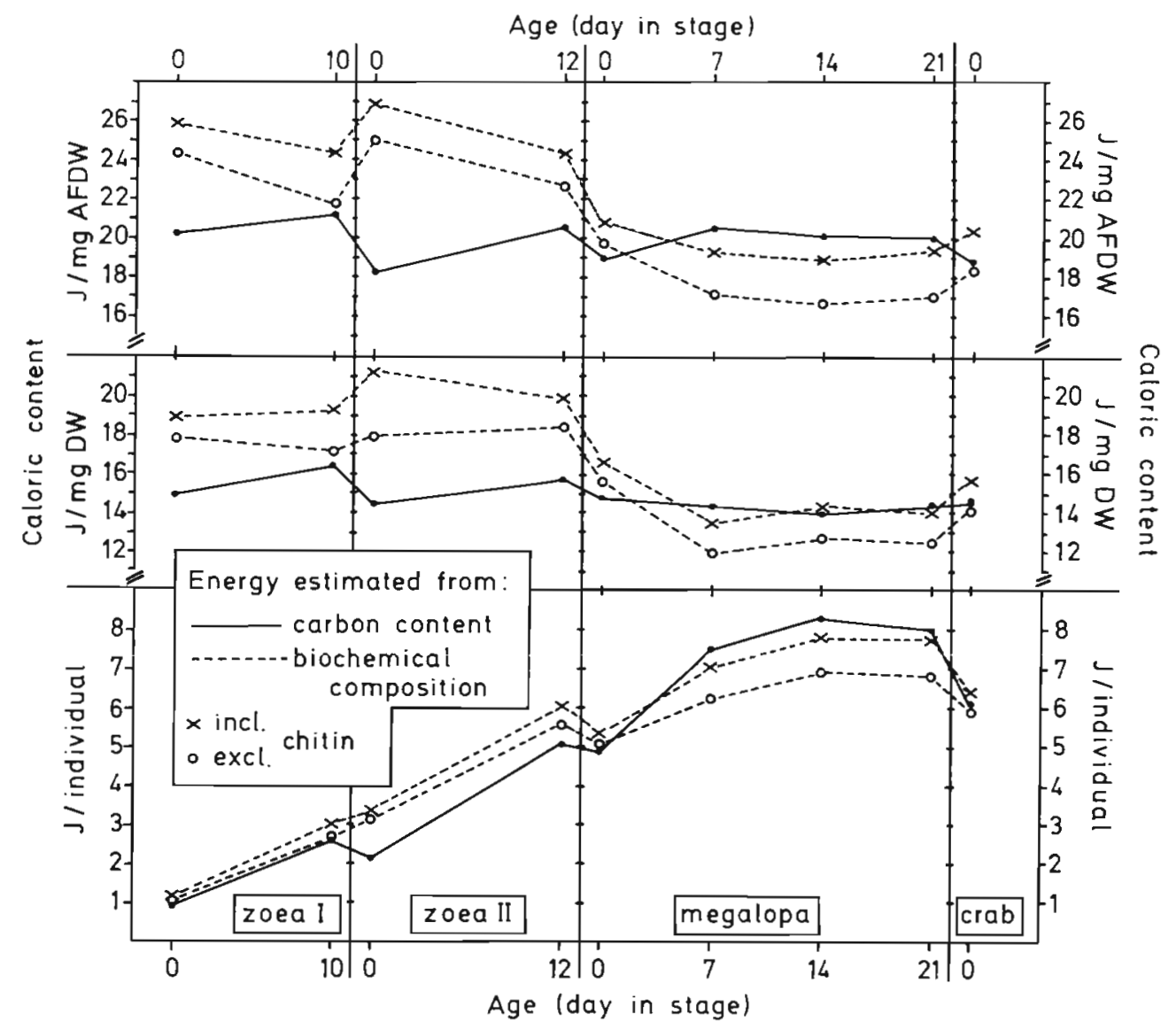

Fig. 3. Hyas araneus. Individual and weight-specific energy equivalents in larvae and freshly metamorphosed crabs, calculated separately from carbon content and biochemical composition (for conversions see 'Material and Methods'), the latter both with and without chitin

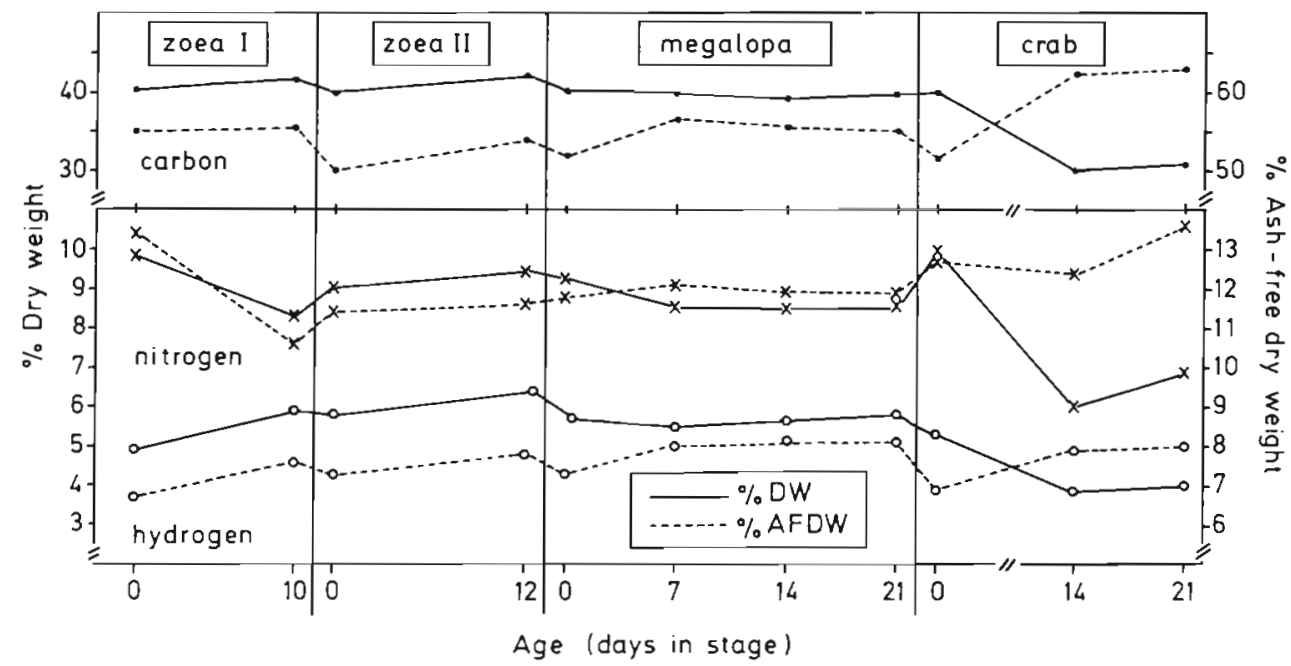

Fig. 4. Hyas araneus. Elemental composition (carbon, nitrogen, hydrogen) during larval and early post-larval development. Given are percentages of dry weight and ash-free dry weight 


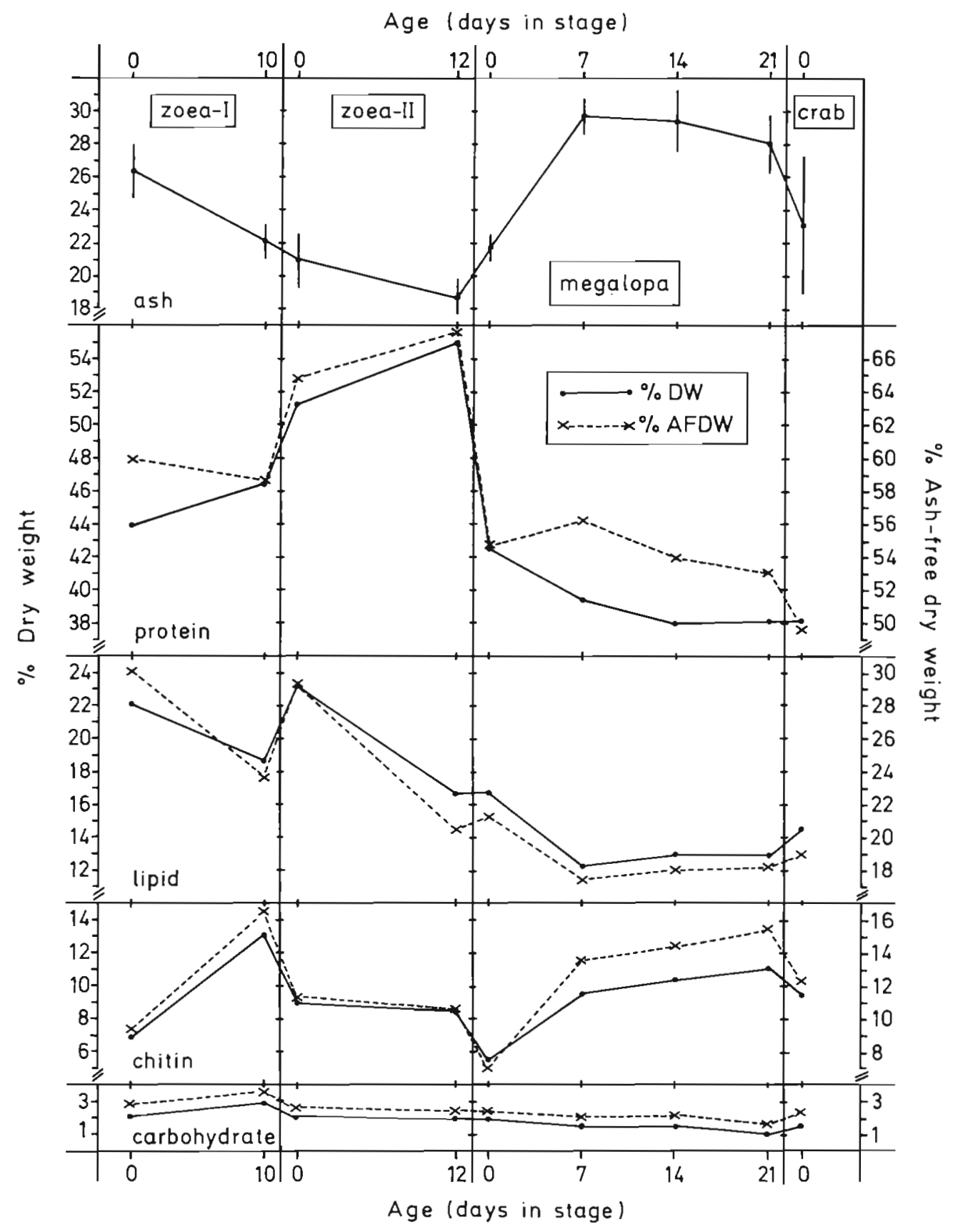

Fig. 5. Hyas araneus. Gross biochemical composition in larvae and freshly metamorphosed crabs. Given are percentages of dry weight (DW) and ash-free dry weight (AFDW). Ash content expressed as \% DW \pm standard deviation

ously decreasing tendency with a maximum value of $30 \%$ AFDW in the freshly hatched zoea-l and a minimum of ca. $17 \%$ in the megalopa.

Chitin also showed cyclical variations; these are more easily recognizable in absolute (Fig. 1) than in relative values (Fig. 5): During each stage the cuticle was reinforced considerably, but most of it was later cast as exuvia. The share of biomass ranged between ca. 7 and $17 \%$ AFDW.

Carbohydrate content varied between only 1.6 and $3.7 \%$ AFDW. During larval development relative values showed a decreasing tendency. 


\section{Interrelation between elemental and biochemical constituents}

Known statistical interrelations between single chemical components can be used to predict unknown amounts from measured ones. Various authors (e.g. Raymont et al., 1964; Pandian and Schumann, 1967; Champalbert and Kerambrun, 1978) calculated protein content from total nitrogen, multiplying its amount by 6.25. This conversion is based on 2 assumptions: (1) nitrogen always accounts to ca. $16 \%$ of protein weight, regardless of specific amino acid composition; (2) nonprotein nitrogen (from free amino acids, nucleic acids, excretory substances, etc.) does not play a conspicuous role.

Fig. 6 shows that all protein values measured directly were below the theoretical level (6.25 times nitrogen). This indicates that non-protein $N$ occurs in considerable amounts throughout larval development of Hyas araneus. When chitin-N (6\% of chitin) is subtracted from total nitrogen figures, protein is still consistently much below the above theoretical line. Thus, chitin contributes only little to the total amount of nonprotein nitrogen. Fit of observed data of protein and those predicted from nitrogen was best when using a non-linear model. Regression curves and equations are given in Fig. 6.

Prediction of protein from carbon yields again a good fit ( $r=0.982$; Fig. 6). Lipid can be calculated from both carbon and hydrogen values (Fig. 7). The amount of carbohydrate was always so low that measurements were relatively inaccurate, showing high variation. Consequently, predictions of carbohydrate from carbon are less satisfactory $(r=0.874$; Fig. 7 ).

\section{DISCUSSION}

During larval development of Hyas araneus there is a multiplication of biomass and of all its constituents. Relative gain (expressed as \% initial weight), decreased from zoea-I to megalopa. This is in contrast to other decapod species: in the anomuran Pagurus bernhardus the megalopa stage does not take up food and thus loses biomass instead of gaining weight (Dawirs, 1980, 1981). In the portunid crab Carcinus maenas, this stage gains nearly twice the amount accumulated in all 4 zoeal stages combined (Dawirs, 1980).

The growth pattern in megalopae of Hyas araneus remains unclear to some degree: in accordance with Anger and Dawirs (1982) our data suggest that there is a loss of biomass during the latest phase of this instar. In contrast to Pagurus bernhardus and other hermit crab species (for discussion see Dawirs, 1981), food is regularly taken up also during the period preceding metamorphosis. Ingestion rate, however, apparently does not meet actual metabolic needs, so that losses result in organic body compounds. Reduced feeding activity is suggested also by lack of cannibalism and by almost $100 \%$ survival during food deprivation in late megalopae.

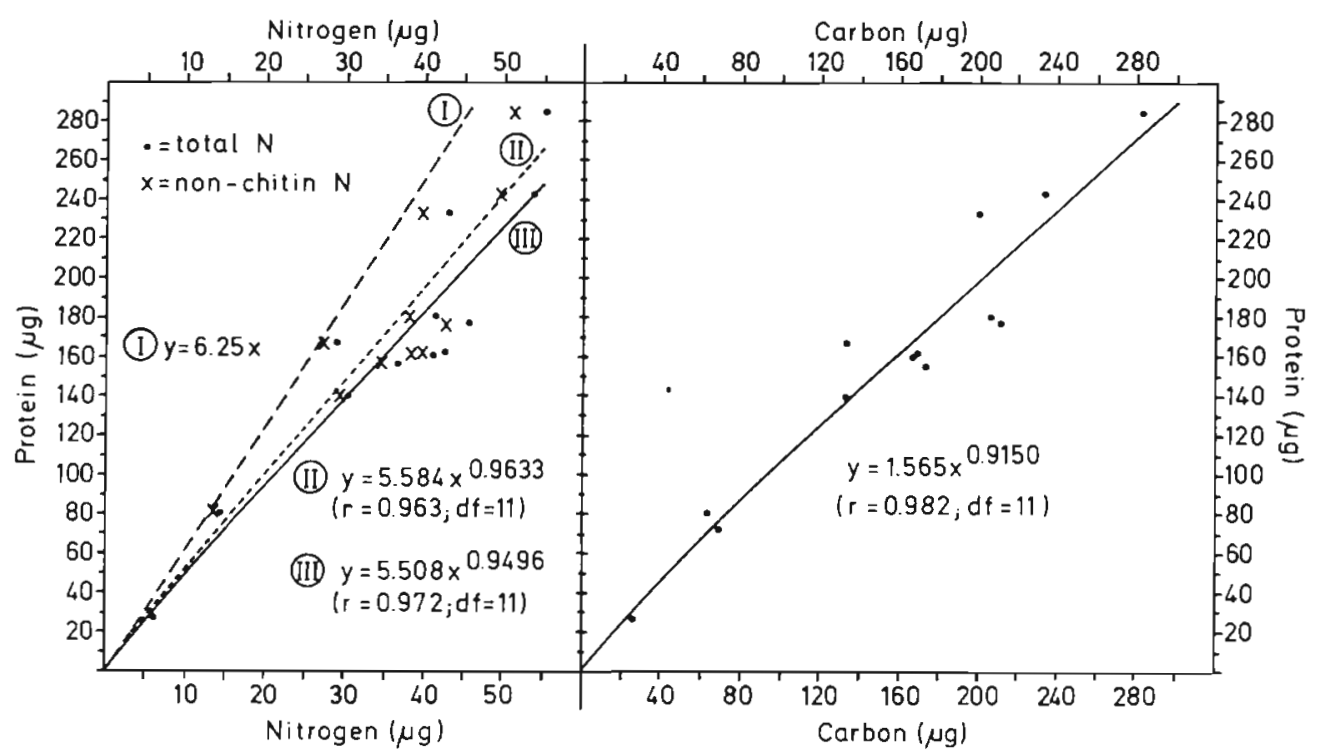

Fig. 6. Hyas araneus. Interrelations between nitrogen $(\mathrm{N})$ and protein (left) and between carbon (C) and protein (right) in larvae and freshly metamorphosed crabs. x C, $N_{i}$ y protein; r correlation coefficient; df degrees of freedom. Left: I theoretical conversion by multiplication of $\mathrm{N}$ with 6.25 ; II, III non-linear regressions with non-chitin $\mathrm{N}$ and total $\mathrm{N}$, respectively, as independent variable $(x)$ 


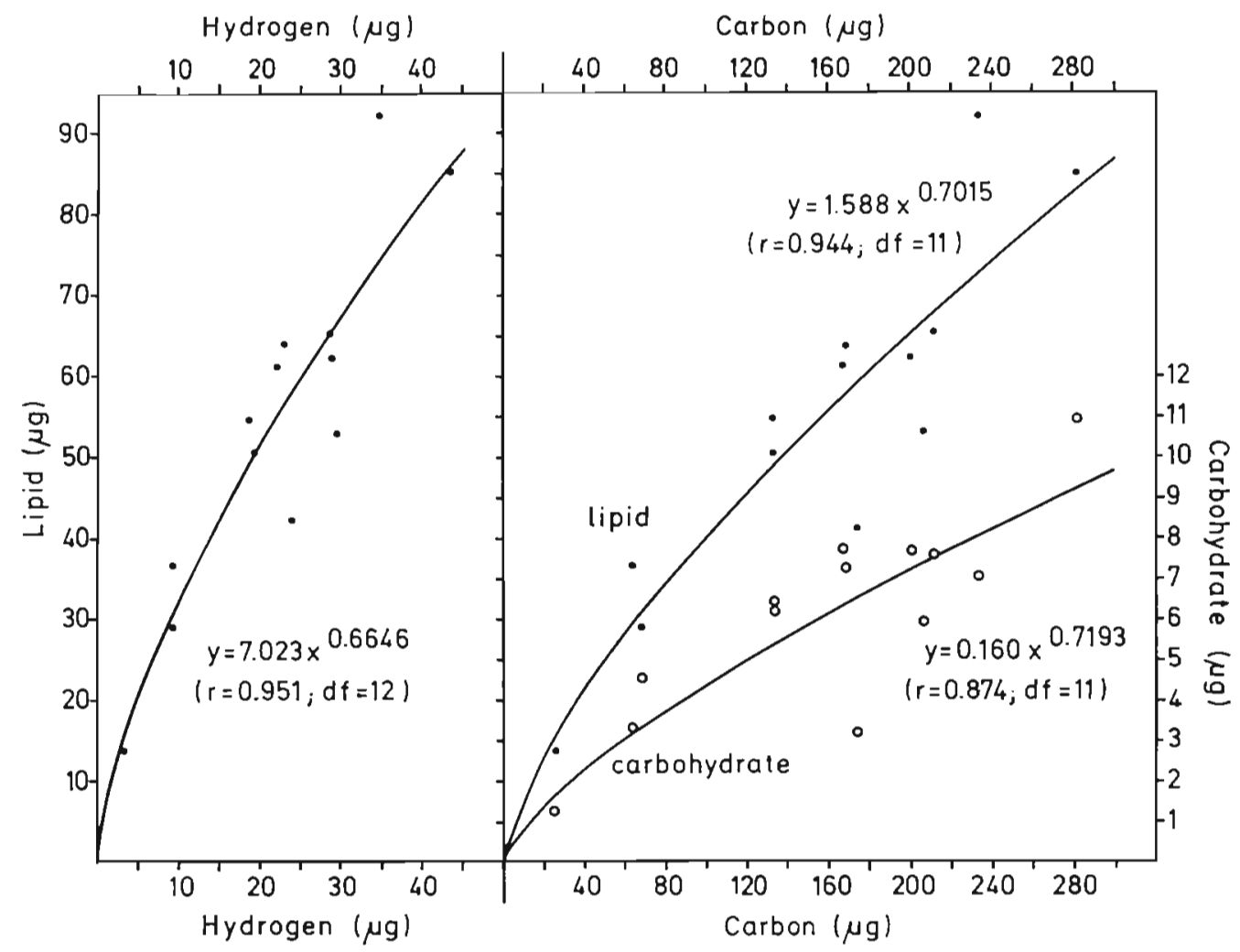

Fig. 7. Hyas araneus. Interrelations between hydrogen $(\mathrm{H})$ and lipid (left), between carbon (C) and lipid, and between $\mathrm{C}$ and

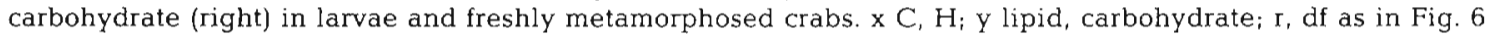

Very steep increase in biomass during the first crab stage indicated that growth pattern changes considerably after metamorphosis. This may be attributed to the fact that during juvenile growth there is almost no further morphological development; the latter was strong in the preceding larval stages. Thus, there must be a shift in partitioning of assimilated matter and energy toward mere body growth in juvenile crabs.

Since energy equivalents were calculated from chemical composition, they follow the growth patterns discussed above. Their order of magnitude compares favourably with most figures given in the literature for aquatic crustaceans, estimated in different ways (e.g. Pandian and Schumann, 1967; Cummins and Wuycheck, 1971; Childress and Nygaard, 1974; Mootz and Epifanio, 1974; Lemcke and Lampert, 1975; Griffith, 1977; Logan and Epifanio, 1978; Levine and Sulkin, 1979; Stephenson and Knight, 1980; Dawirs, 1980 , 1981; Youngbluth, 1982). There are, however, systematic differences between values calculated from carbon and those obtained from biochemical composition of practically identical material. Direct calorimetry would probably yield somewhat different data again. For more accurate estimates of caloric contents, first of all the ecological or physiological problem in mind has to be defined clearly. There are, for example, different factors converting biochemical compounds to energy (for discussion see Childress and Nygaard, 1974). Furthermore, intercalibration of different methods is probably neccessary, at least for every major taxon. In Hyas araneus as in other crustaceans, the amount of inorganic carbon must also be determined to avoid overestimation of energy, when the conversion by Salonen et al. (1976) is applied. Even when methods of direct calorimetry are used the ecological or physiological significance of the chemical energy measured must be taken into consideration for further interpretation.

In Hyas araneus larvae and juveniles, protein was the most prominent constituent. This was already suggested by Anger and Nair (1979), and reported from some other decapod larvae (Pandian and Schumann, 1967; Capuzzo and Lancaster, 1979) and adult pelagic marine crustaceans (e. g. Raymont et al., 1964, 1967; Childress and Nygaard, 1974; Clarke, 1980). Unfortunately, there is almost no information on changes in biochemical composition during larval development of decapod crustaceans. Hence hardly any comparison is possible on the basis of present knowledge: Capuzzo and Lancaster (1979) found almost constant values throughout larval development of lobster Homarus americanus, with protein slightly declining from as 
much as 84 to $81 \%$, and chitin increasing from 10 to $16 \%$ AFDW. Lipid was much less important in this case (only 4 to $7 \%$ AFDW), with a slightly decreasing tendency toward metamorphosis. In larvae of Rhithropanopeus harrisii, Frank et al. (1975) surprisingly found more lipid than protein (values given in \% fresh weight unfortunately), where both components increased from zoea-I to megalopa. In $H$. araneus, percentage of protein increased during zoeal development, but decreased in the megalopa, whereas lipid showed a decreasing tendency from hatching to metamorphosis. The only consistent result in the few investigations published so far, is that carbohydrate plays a minor role in pelagic marine crustaceans (e.g. Raymont et al., 1964, 1967; Anger and Nair, 1979; Capuzzo and Lancaster, 1979; Clarke, 1980).

Elemental composition (C, N, H) of larval Hyas araneus is similar to that of most other pelagic crustaceans investigated (e.g. Childress and Nygaard, 1974; Ikeda, 1974; Omori, 1979; Dawirs, 1980, 1981). Predictions of biochemical data from elemental data appear rather reliable, as long as they are restricted to the species investigated (Figs. 6 and 7). Conversion of nitrogen to protein by multiplication with 6.25 results generally in an overestimation of protein. This is supported by almost identical findings by Childress and Nygaard (1974; see their Fig. 5) and by data given by Mayzaud and Martin (1975). The amount of overestimation, however, might be smaller than suggested by Fig. 6, since some losses of proteins may occur during the analytical procedure. Future investigations will have to determine the extent to which our conversions to biochemical constituents can be generalized. So far, they must be considered appropriate for rough estimates in $H$. araneus and possibly other brachyuran larvae. They are a preliminary basis for future comparative studies on decapod larval energetics.

Acknowledgements. This research was supported by Bundesministerium für Forschung und Technologie, Bonn (Grant No. MFU - 0502/7). We wish to thank also Ms. A. Vogt and Mr. G. Hobusch, who helped in rearing experiments, Ms. B. Lämmel, who made the drawings, and Dr. M. Rieper, who corrected the manuscript.

\section{LITERATURE CITED}

Anger, K., Dawirs, R. R. (1981). Influence of starvation on the larval development of Hyas araneus (Decapoda Majidae). HeIgoländer Meeresunters. 34: 287-311

Anger, K. Dawirs, R. R. (1982). Elemental composition (C, N, $\mathrm{H}$ ) and energy in growing and starving larvae of Hyas araneus (Decapoda, Majidae). Fish. Bull. U. S. 80: 419-433

Anger, K., Nair, K. K. C. (1979). Laboratory experiments on the laval development of Hyas araneus (Decapoda, Majidae). Helgoländer wiss. Meeresunters. 32: 36-54

Capuzzo, J. M., Lancaster, B. A. (1979). Some physiological and biochemical considerations of larval development in the American lobster, Homarus americanus MilneEdwards. J. exp. mar. Biol. Ecol. 40: 53-62

Champalbert, G., Kerambrun, P. (1978). Composition biochimique des copépodes de l'hyponeuston de Méditerranée Nord occidentale. Poids sec et analyse élémentaire du carbone, de l'hydrogène et de l'azote. Mar. Biol. 45: 215-224

Childress, J. J., Nygaard, M. (1974). Chemical composition and buoyancy of midwater crustaceans as function of depth of occurrence off Southern California. Mar. Biol. 27 : $225-238$

Christiansen, M. E. (1971). Larval development of Hyas araneus (Linnaeus) with and without antibiotics (Decapoda, Brachyura, Majidae). Crustaceana 21: 307-315

Christiansen, M. E., Størmer, F. C. (1978). Effects of the watersoluble fraction of Ekofisk crude oil on zoeal larvae of the crab Hyas araneus. Ambio 7: 23-25

Clarke, A. (1980). The biochemical composition of krill, Euphausia superba Dana, from South Georgia. J. exp. mar. Biol. Ecol. 43: 221-236

Cummins, K. W., Wuycheck, J. C. (1971). Caloric equivalents for investigations in ecological energetics. Mitt. int. Verein. Limnol. 18: 1-158

Dawirs, R. R. (1980). Elemental composition (C, H, N) in larval and crab-1 stages of Pagurus bernhardus (Decapoda, Paguridae) and Carcinus maenas (Decapoda, Portunidae). Mar. Biol. 57: 17-23

Dawirs, R. R. (1981). Elemental composition (C, N, H) and energy in the development of Pagurus bernhardus (Decapoda, Paguridae) megalopa. Mar. Biol. 64: 117-123

Dawirs, R. R. (in press). Respiration, energy balance and developmental pattern in growing and starving larvae of Carcinus maenas L. (Decapoda, Portunidae). J. exp. mar. Biol. Ecol.

Folin, O., Malmros, H. (1929). An improved form of Folin's micro method for blood sugar determinations. J. Biol. Chem. 83: 115-120

Frank, R. J., Sulkin, S. D., Morgan, R. P. (1975). Biochemical changes during larval development of the xanthid crab Rhithropanopeus harrisii. I. Protein, total lipid, alkaline phosphatase, and glutamic oxaloacetic transaminase. Mar. Biol. 32: 105-111

Griffiths, D. (1977). Caloric variation in crustacea and other animals. J. Anim. Ecol. 46: 593-605

Hirota, J., Szyper, J. P. (1975). Separation of total particulate carbon into inorganic and organic components. Limnol Oceanogr. 20: 896-900

Holland, D. L., Gabbot, P. A (1971) A micro-analytical scheme for the determination of protein, carbohydrate, lipid and RNA levels in marine invertebrate larvae. J. mar. biol. Ass. U. K. 51: 659-668

Holland, D. L., Hannant, P. J. (1973). Addendum to a microanalytical scheme for the biochemical analysis of marine invertebrate larvae. J. mar. biol. Ass. U. K. 53: 833-838

Ikeda, T. (1974). Nutritional ecology of marine zooplankton. Mem. Fac. Fish. Hokkaido Univ. 22: 1-97

Kunisch, M. (1982). Einfluß von Bedingungen der Embryonalund Larvalentwicklung auf das Wachstum juveniler Hyas araneus L. (Decapoda). Diplomarbeit, Universität Mainz, p. $1-86$

Lemcke, H. W., Lampert, W. (1975). Veränderungen im Gewicht und der chemischen Zusammensetzung von Daphnia pulex im Hunger. Arch. Hydrobiol. 48 (Suppl.): 108-137 
Levine, D. M., Sulkin, S. D. (1979). Partitioning and utilization of energy during the larval development of the xanthid crab, Rhithropanopeus harrisii (Gould). J. exp. mar. Biol. Ecol. 40: 247-257

Logan, D. T., Epifanio, C. E. (1978). A laboratory energy balance for the larvae and juveniles of the American lobster Homarus americanus Mar. Biol. 47: 381-389

Lowry, D. H., Rosenberg, N. J., Farr, A. L., Randall, R. J. (1951). Protein measurement with the folin phenol reagent. J. Biol. Chem. 193: 265-275

Marsh, J. B., Weinstein, D. B. (1966). Simple charring method for determination of lipids. J. Lipid Res. 7: 574-576

Mayzaud, P., Martin, J. L. M. (1975). Some aspects of the biochemical and mineral composition of marine plankton. J. exp. mar. Biol. Ecol. 17: 297-310

Mootz, C. A., Epifanio, C. E. (1974). An energy budget for Menippe mercenaria larvae fed Artemia nauplii. Biol. Bull. mar, biol. Lab., Woods Hole 146: 44-55

Omori, M. (1969). Weight and chemical composition of the major zooplankton in the North Pacific Ocean. Mar. Biol. 3: $4-10$

Omori, M. (1979). Growth, feeding, and mortality of larval and early postlarval stages of the oceanic shrimp Sergestes similis Hansen. Limnol. Oceanogr. 24: 273-288

Pandian, T. J., Schumann, K.-H. (1967). Chemical composi- tion and caloric content of egg and zoea of the hermit crab Eupagurus bernhardus. Helgoländer wiss. Meeresunters. 16: $225-230$

Raymont, J. E. G., Austin, J., Linford, E. (1964). Biochemical studies on marine zooplankton. I. The biochemical composition of Neomysis integer. J. Cons. int. Explor. Mer 28: $354-363$

Raymont, J. E. G., Austin, J., Linford, E. (1967). The biochemical composition of certain oceanic zooplanktonic decapods. Deep Sea Res. 14: 113-115

Salonen, K., Sarvala, J., Hakala, I., Viljanen, M.-L. (1976). The relation of energy and organic carbon in aquatic invertebrates. Limnol. Oceanogr. 21: 724-730

Stephenson, M. J., Knight, A. W. (1980). Growth, respiration and caloric content of larvae of the prawn Macrobrachium rosenbergii. Comp. Biochem. Physiol. 66 A: 385-391

Winberg, G. G. (1971). Methods for the estimation of production of aquatic animals. Academic Press, London

Yamaoka, L. H., Scheer, B. T. (1970). Chemistry of growth and development in crustaceans. In: Florkin, M., Scheer, B.T. (eds.) Chemical zoology, Vol. V, Arthropoda. Academic Press, New York, p. 321-341

Youngbluth, M. J. (1982). Utilization of a faecal mass as food by the pelagic mysis larva of the penaeid shrimp Solenocera atlantidis. Mar. Biol. 66: 47-51

This paper was presented by Professor H.-P. Bulnheim; it was accepted for printing on February 13, 1983 